\section{Tris 1-Nitroso-2-naphtholate Complex of Ruthenium(II): An Efficient Building Unit for Polynuclear Complexes}

\section{Anjan Kumar Das, ${ }^{\dagger}$ Angel Rueda, ${ }^{\dagger}$ Larry R. Falvello, Shie-Ming Peng, ${ }^{\S}$ and Samaresh Bhattacharya ${ }^{*, \dagger}$}

Department of Chemistry, Inorganic Chemistry Section, Jadavpur University, Calcutta 700032, India, Department of Inorganic Chemistry, Faculty of Science, University of Zaragoza, E-50009 Zaragoza, Spain, and Department of Chemistry, National Taiwan University, Taipei, Taiwan, ROC

Received February 17, 1999

\section{Introduction}

The chemistry of polynuclear transition metal complexes has been of immense current interest, ${ }^{1-12}$ because of the fascinating and versatile properties exhibited by them. The obvious prerequisite for studies on the chemistry of such complexes is the construction of polynuclear assemblies of predesigned compositions. Among the various synthetic methodologies that are followed for this purpose, the stepwise synthetic approach based on preparing mononuclear building units first and then linking them in a desired fashion has been of significant advantage, particularly with regard to having a chemical control over the synthetic procedure. Transition metal complexes of ligands with unutilized donor sites are a popular choice as the building unit, because they can be used as "ligands" to bind to other metals. Polydentate ligands, which can bind to a metal ion using some of its available donor sites while the other sites remain uncoordinated, are of significant importance in this respect. In the present study we have explored such a possibility in 1-nitroso-2-naphthol (1), which is abbreviated as HL where $\mathrm{H}$ stands for the dissociable proton. This ligand tautomerizes to the corresponding keto-oxime form (2), and hence the dissociated anionic ligand $\left(\mathrm{L}^{-}\right)$is best represented as shown in 3. The anionic ligand is known ${ }^{13}$ to coordinate metal ions as a bidentate $\mathrm{N}, \mathrm{O}$ donor forming a five-membered chelate ring (4) leaving the oximato oxygen available for further coordination to a second metal ion (5), and thus it can act as a bridging ligand. Such bridging ability of the oximate function has been successfully utilized by many workers. ${ }^{14-19}$ Mononuclear com-

\footnotetext{
Jadavpur University.

$\doteqdot$ University of Zaragoza

$\S$ National Taiwan University.

(1) Chisholm, M. H. Chem. Soc. Rev. 1995, 24, 79.

(2) Ward, M. D. Chem. Soc. Rev. 1995, 24, 121

(3) Teo, B. K.; Zhang, H. Coord. Chem. Rev. 1995, 143, 611

(4) Balzani, V.; Juris, A.; Venturi, M.; Campagna, S.; Serroni, S. Chem. Rev. 1996, 96, 759.

(5) Raper, E. S. Coord. Chem. Rev. 1997, 165, 554.

(6) Belser, P.; Bernhard, S.; Jandrascs, E.; Zelewsky, A. V.; Cola, L. D.; Balzani, V. Coord. Chem. Rev. 1997, 159, 1.

(7) Keena, F. R. Coord. Chem. Rev. 1997, 159, 121

(8) Wu, Y.; Pfenning, B. W.; Sharp, S. L.; Ludwig, D. R.; Warren, C. J.; Vecenzi, E. P.; Bocarsly, A. B. Coord. Chem. Rev. 1997, 159, 245.

(9) Yoshimura, A.; Zaki, K. N.; Ohno, T. Coord. Chem. Rev. 1997, 159, 375.

(10) Astruc, D. Acc. Chem. Res. 1997, 30, 383.

(11) Anson, F. C.; Shi, C.; Steiger, B. Acc. Chem. Res. 1997, 30, 437.

(12) Keene, F. R. Chem. Soc. Rev. 1998, 27, 185.

(13) Saarinen, H.; Karvenranta, J. Acta Chem. Scand. A 1975, 29, 409
}<smiles>C=Nc1c(C)ccc2ccccc12</smiles>

1

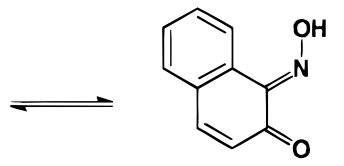

2

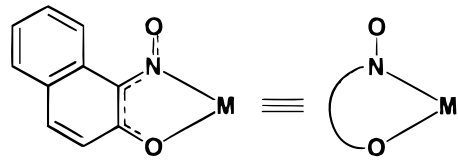

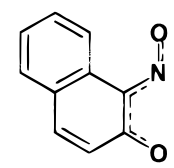

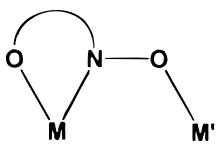

5 plexes of 1-nitroso-2-naphtholate ligand may therefore be expected to serve as building units for the construction of polynuclear assemblies. Herein we describe the synthesis and characterization of tris(1-nitroso-2-naphtholate)ruthenium(II) and its utilization as an efficient building unit to form heterometallic trinuclear complexes.

\section{Experimental Section}

Materials. Commercial ruthenium trichloride was purchased from Arora Matthey, Calcutta, India, and was converted to $\mathrm{RuCl}_{3} \cdot 3 \mathrm{H}_{2} \mathrm{O}$ by repeated evaporation with concentrated hydrochloric acid. 1-Nitroso2-naphthol was purchased from Loba-Chemie, Mumbai, India. Nickel perchlorate $\left(\mathrm{Ni}\left(\mathrm{ClO}_{4}\right)_{2} \cdot 6 \mathrm{H}_{2} \mathrm{O}\right)$ was prepared by treating $\mathrm{NiCO}_{3}$ with $70 \%$ perchloric acid. Purification of acetonitrile and preparation of tetraethylammonium perchlorate (TEAP) for electrochemical work were performed as before. ${ }^{20}$

Preparation of $\mathbf{H N E t}_{3}\left[\mathbf{R u}(\mathbf{L})_{3}\right]$. To a solution of $\mathrm{RuCl}_{3} \cdot 3 \mathrm{H}_{2} \mathrm{O}(100$ $\mathrm{mg}, 0.10 \mathrm{mmol})$ in ethanol $\left(40 \mathrm{~cm}^{3}\right)$ was added HL $(211 \mathrm{mg}, 0.32$ mmol) followed by $\mathrm{NEt}_{3}(123 \mathrm{mg}, 1.23 \mathrm{mmol})$. The solution was then refluxed for $2 \mathrm{~h}$. A blue precipitate started to separate during reflux. After cooling of the solution to room temperature, the precipitate was collected by filtration, washed thoroughly with water, and dried in vacuo over $\mathrm{P}_{4} \mathrm{O}_{10}$. Recrystallization of the crude product from 1:2 acetonitrilebenzene solution gave $\mathrm{HNEt}_{3}\left[\mathrm{Ru}(\mathrm{L})_{3}\right]$ as a blue crystalline solid. Yield: $65 \%$. Anal. Calcd for $\mathrm{C}_{36} \mathrm{H}_{34} \mathrm{~N}_{4} \mathrm{O}_{6} \mathrm{Ru}$ : C, 60.08; H, 4.73; N, 7.79. Found: C, 60.12; H, 4.75; N, 7.77.

Preparation of $\left[\left\{\mathbf{R u}(\mathbf{L})_{3}\right\}_{2} \mathbf{N i}\right]$. To a solution of $\mathrm{HNEt}_{3}\left[\mathrm{Ru}(\mathrm{L})_{3}\right](100$ $\mathrm{mg}, 0.14 \mathrm{mmol})$ in ethanol $\left(40 \mathrm{~cm}^{3}\right)$ was added $\mathrm{Ni}\left(\mathrm{ClO}_{4}\right)_{2} \cdot 6 \mathrm{H}_{2} \mathrm{O}(25$ $\mathrm{mg}, 0.07 \mathrm{mmol}$ ). The solution was then refluxed for $3 \mathrm{~h}$. Upon partial evaporation of the solution, a blue precipitate of $\left[\left\{\mathrm{Ru}(\mathrm{L})_{3}\right\}_{2} \mathrm{Ni}\right]$ was obtained, which was collected by filtration, washed thoroughly with water, and dried in vacuo over $\mathrm{P}_{4} \mathrm{O}_{10}$. Recrystallization of the crude product from 1:2 acetonitrile-benzene solution gave $\left[\left\{\mathrm{Ru}(\mathrm{L})_{3}\right\}_{2} \mathrm{Ni}\right]$ as a blue crystalline solid. Yield: $62 \%$. Anal. Calcd for $\mathrm{C}_{60} \mathrm{H}_{36} \mathrm{~N}_{6} \mathrm{O}_{12} \mathrm{Ru}_{2-}$ Ni: C, 55.69; H, 2.78; N, 6.50. Found: C, 55.73; H, 2.77; N, 6.51

(14) Manivannam, V.; Dutta, S.; Basu, P.; Chakravorty, A. Inorg. Chem 1993, 32, 4807 and references therein.

(15) Birkelbach, F.; Winter, M.; Florke, U.; Haupt, H. J.; Butzlaff, C.; Lengen, M.; Bill, E.; Trautwein, A. X.; Wieghardt, K.; Chaudhuri, P. Inorg. Chem. 1994, 33, 3990.

(16) Ruiz, R.; Julva, M.; Faus, J.; Lloret, F.; Munoz, M. C.; Journaux, Y.; Bois, C. Inorg. Chem. 1997, 36, 3434.

(17) Birkelbach, F.; Weyhemuller, T.; Lengen, M.; Gerdan, M.; Trautwein, A. X.; Wieghardt, K.; Chaudhuri, P. J. Chem. Soc., Dalton Trans. 1997, 4529.

(18) Xu, D.; Gu, J.; Xu, L.; Liang, K.; Xu, Y. Polyhedron 1998, 17, 231.

(19) Burdinski, D.; Birkelbach, F.; Weyhermuller, T.; Florke, U.; Haupt, H. J.; Lengen, M.; Trautwein, A. X.; Bill, E.; Wieghardt, K.; Chaudhuri, P. Inorg. Chem. 1998, 37, 1009.

(20) Basuli, F.; Ruf, M.; Pierpont, C. G.; Bhattacharya, S. Inorg. Chem. 1998, 37, 6113 . 
Table 1. Crystallographic Data

\begin{tabular}{lll}
\hline & $\mathrm{HNEt}_{3}\left[\mathrm{Ru}(\mathrm{L})_{3}\right] \cdot 2 \mathrm{C}_{6} \mathrm{H}_{6}$ & {$\left[\left\{\mathrm{Ru}(\mathrm{L})_{3}\right\}_{2} \mathrm{Ni} \cdot 6 \mathrm{C}_{6} \mathrm{H}_{6}\right.$} \\
\hline empirical formula & $\mathrm{C}_{48} \mathrm{H}_{46} \mathrm{~N}_{4} \mathrm{O}_{6} \mathrm{Ru}$ & $\mathrm{C}_{96} \mathrm{H}_{72} \mathrm{~N}_{6} \mathrm{NiO}_{12} \mathrm{Ru}_{2}$ \\
fw & 875.96 & 1762.45 \\
space group & hexagonal, $P 6_{3}$ & rhombohedral, $R \overline{3} c$ \\
$a, \AA$ & $16.085(1)$ & $14.9517(1)$ \\
$b, \AA$ & $16.085(1)$ & $14.9517(1)$ \\
$c, \AA$ & $18.585(2)$ & $62.6021(3)$ \\
$V, \AA^{3}$ & $4165(1)$ & $12119.94(13)$ \\
$Z$ & 4 & 6 \\
$\rho_{\text {calcd }}, \mathrm{g} \mathrm{cm}^{-3}$ & 1.397 & 1.449 \\
$\rho_{\text {obsd }}, \mathrm{g} \mathrm{cm}^{-3}$ & 1.400 & 1.500 \\
$\lambda, \AA$ & 0.71073 & 0.71073 \\
cryst size, mm $_{T,}$ & $0.35 \times 0.18 \times 0.13$ & $0.18 \times 0.15 \times 0.10$ \\
$T,{ }^{\circ} \mathrm{C}$ & -123 & 22 \\
$\mu, \mathrm{mm}^{-1}$ & 0.432 & 0.669 \\
$\mathrm{R} 1^{a}$ & 0.0507 & 0.0617 \\
wR2 $^{b}$ & 0.1384 & 0.1085 \\
$\mathrm{GOF}$ on $F^{2 c}$ & 1.045 & 1.100
\end{tabular}

${ }^{a} \mathrm{R} 1=\sum|| F_{\mathrm{o}}|-| F_{\mathrm{c}}|| / \sum\left|F_{\mathrm{o}}\right|{ }^{b} \mathrm{wR} 2=\left[\sum\left[w\left(F_{\mathrm{o}}{ }^{2}-F_{\mathrm{c}}{ }^{2}\right)^{2}\right] / \sum\left[w\left(F_{\mathrm{o}}{ }^{2}\right)^{2}\right]\right]^{1 / 2}$. ${ }^{c} \mathrm{GOF}=\left[\sum\left[w\left(F_{\mathrm{o}}{ }^{2}-F_{\mathrm{c}}{ }^{2}\right)^{2}\right] /(M-N)\right]^{1 / 2}$, where $M$ is the number of reflections and $N$ is the number of parameters refined.

Physical Measurements. Microanalyses $(\mathrm{C}, \mathrm{H}, \mathrm{N})$ were performed using a Perkin-Elmer 240C elemental analyzer. IR spectra were obtained on a Perkin-Elmer 783 spectrometer with samples prepared as $\mathrm{KBr}$ pellets. Electronic spectra were recorded on a Shimadzu UV-1601 spectrophotometer. Emission spectra were recorded on a Spex Fluorolog spectrofluorimeter. Magnetic susceptibilities were measured using a PAR 155 vibrating sample magnetometer. ${ }^{1} \mathrm{H}$ NMR spectra were obtained on a Brucker AC-200 NMR spectrometer using TMS as the internal standard. Electrochemical measurements were made using a PAR model 273 potentiostat. A platinum-disk working electrode, a platinum-wire auxiliary electrode- and an aqueous saturated calomel reference electrode (SCE) were used in a three-electrode configuration. A platinum-wire gauze electrode was used in the coulometric experiments. A RE $0089 \mathrm{X}-\mathrm{Y}$ recorder was used to trace the voltammograms. Electrochemical measurements were made under a dinitrogen atmosphere. All electrochemical data were collected at $298 \mathrm{~K}$ and are uncorrected for junction potentials.

Crystallography of $\mathbf{H N E t}_{3}\left[\mathbf{R u}(\mathbf{L})_{3}\right] \cdot \mathbf{2 C}_{6} \mathbf{H}_{6}$. Single crystals were grown by slow diffusion of benzene into an acetonitrile solution of the complex. Selected crystal data and data collection parameters are given in Table 1. The unit cell dimensions were determined by a least-squares fit of 25 centered reflections $\left(22.0^{\circ} \leq \theta \leq 28.8^{\circ}\right)$. Data were collected on an Enraf Nonius CAD-4 diffractometer using graphite-monochromated Mo K $\alpha$ radiation $(\lambda=0.71073 \AA)$ by $\omega$ scans within the angular range $1.77^{\circ}<\theta<31.21^{\circ}$. Three standard reflections were used to check the crystal stability toward X-ray exposure, and they showed no significant intensity variation over the course of data collection. X-ray data reduction and structure solution and refinement were done using the SHELXTL-PLUS package. The structure was solved by an automated Patterson interpretation routine. Final cycles of refinement converged with discrepancy indices of $\mathrm{R} 1=0.0507$ and $\mathrm{wR} 2=0.1384$.

Crystallography of $\left[\left\{\mathbf{R u}(\mathrm{L})_{3}\right\}_{2} \mathbf{N i}\right] \cdot \mathbf{6 C}_{6} \mathbf{H}_{6}$. Single crystals were grown by slow diffusion of benzene into an acetonitrile solution of the complex. Selected crystal data and data collection parameters are given in Table 1 . The unit cell dimensions were determined by a least-squares fit of 25 centered reflections $\left(15^{\circ} \leq \theta \leq 30^{\circ}\right)$. Data were collected on a Siemens Smart CCD diffractometer using graphite-monochromated Mo K $\alpha$ radiation $(\lambda=0.71073 \AA)$ by $\theta-2 \theta$ scans within the angular range $1.70^{\circ}<\theta<30.04^{\circ}$. Three standard reflections, used to check the crystal stability toward X-ray exposure, showed no significant intensity variation over the course of data collection. X-ray data reduction and structure solution and refinement were done using the SHELXS-97 package. The structure was solved by the direct method. Final cycles of refinement converged with discrepancy indices of $\mathrm{R} 1=0.0617$ and $\mathrm{wR} 2=0.1085$.

\section{Results and Discussion}

The tris 1-nitroso-2-naphtholate complex of ruthenium(II) was obtained by smooth reaction of 1-nitroso-2-naphthol (HL) with

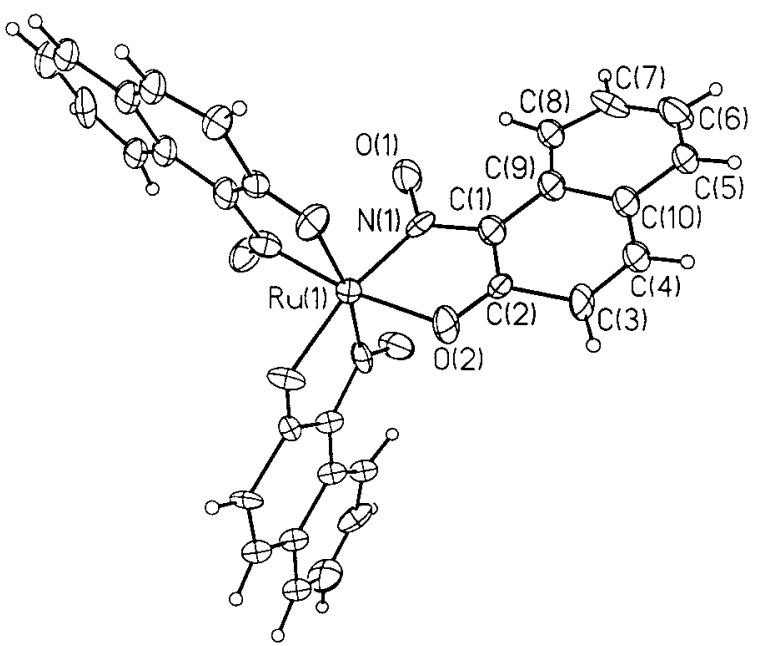

Figure 1. View of the $\left[\mathrm{Ru}(\mathrm{L})_{3}\right]^{-}$anion.

$\mathrm{RuCl}_{3}$ in the presence of $\mathrm{NEt}_{3}$. The complex anion $\left[\mathrm{Ru}^{\mathrm{II}}(\mathrm{L})_{3}\right]^{-}$ has been isolated as the triethylammonium salt. Microanalytical data are in good agreement with the composition of the complex. The complex is diamagnetic, which corresponds to the bivalent state of ruthenium (low-spin $\mathrm{t}_{2}{ }^{6}, S=0$ ) in this complex.

As the 1-nitroso-2-naphtholate ligand is asymmetric, the $\left[\mathrm{Ru}^{\mathrm{II}}(\mathrm{L})_{3}\right]^{-}$complex may exist in two geometric isomeric forms, viz., meridional (6) and facial (7). Chromatographic experiments
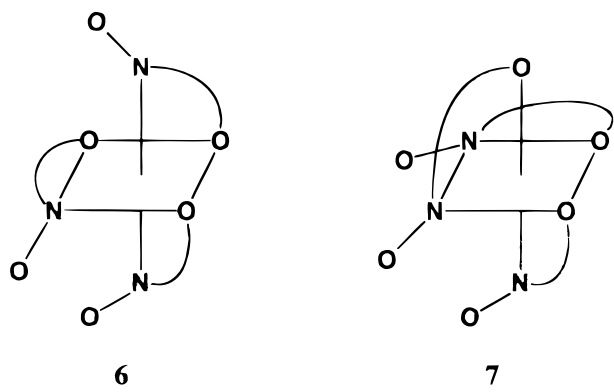

show that the isolated $\mathrm{HNEt}_{3}\left[\mathrm{Ru}(\mathrm{L})_{3}\right]$ complex is isomerically pure. The molecular structure of $\operatorname{HNEt}_{3}\left[\mathrm{Ru}(\mathrm{L})_{3}\right]$ has been determined by $\mathrm{X}$-ray crystallography. ${ }^{21} \mathrm{~A}$ view of the complex anion is shown in Figure 1, and selected bond distances and angles are listed in Table 2. The 1-nitroso-2-naphtholate ligand is coordinated to ruthenium as in 4 with a bite angle of $\sim 80^{\circ}$. The complex has the facial structure (7), with all three nitrogens occupying one triangular face, and the three coordinated oxygens are on the opposite triangular face. Ruthenium lies on a crystallographic 3-fold axis. It may be mentioned here that ferroverdin, a biological pigment, has a chromophore similar to $\left[\mathrm{Ru}^{\mathrm{II}}(\mathrm{L})_{3}\right]^{-22-27}$ The cis geometry is known to be preferred by bivalent ruthenium for maximum $\pi$ interaction. ${ }^{28-30}$ How-

(21) There are two independent one-third $\left[\mathrm{Ru}(\mathrm{L})_{3}\right]^{-}$anions present, related by a noncrystallographic inversion center. The two independent fragments have the same geometry with little quantitative differences. We have restricted our discussion to only one of these $\left[\mathrm{Ru}(\mathrm{L})_{3}\right]^{-}$ fragments.

(22) Chain, E. B.; Tonolo, A.; Carilli, A. Nature 1955, 176, 645.

(23) Ehrenberg, A. Nature 1956, 178, 379.

(24) Ballio, A.; Bertholdt, H.; Chain, E. B.; Vittorio, V. D. Nature 1963, 194, 769.

(25) Ballio, A.; Bertholdt, H.; Carilli, A.; Chain, E. B.; Vittorio, V. D. Tonolo, A.; Vero-Bercellona, L. Proc. R. Soc. London. B 1963, 158, 43.

(26) Neilands, J. B. Stuct. Bonding 1966, 1, 59.

(27) Ballio, A.; Barcellona, S.; Chain, E. B.; Tonolo, A.; Vero-Bercellona, L. Proc. R. Soc. London, B 1964, 161, 384. 
Table 2. Selected Bond Distances and Bond Angles for $\mathrm{HNEt}_{3}\left[\mathrm{Ru}(\mathrm{L})_{3}\right] \cdot 2 \mathrm{C}_{6} \mathrm{H}_{6}$ and $\left[\left\{\mathrm{Ru}(\mathrm{L})_{3}\right\}_{2} \mathrm{Ni}\right] \cdot 6 \mathrm{C}_{6} \mathrm{H}_{6}$

\begin{tabular}{|c|c|c|c|}
\hline \multicolumn{4}{|c|}{$\mathrm{HNEt}_{3}\left[\mathrm{Ru}(\mathrm{L})_{3}\right] \cdot 2 \mathrm{C}_{6} \mathrm{H}_{6}$} \\
\hline $\begin{array}{l}\mathrm{Ru}(1)-\mathrm{N}(1) \\
\mathrm{Ru}(1)-\mathrm{O}(2)\end{array}$ & $\begin{array}{l}\text { Bond Di } \\
1.95(2) \\
2.07(2)\end{array}$ & 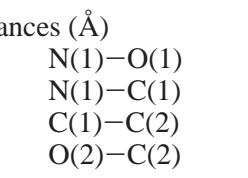 & $\begin{array}{l}1.27(3) \\
1.38(3) \\
1.37(3) \\
1.24(3)\end{array}$ \\
\hline \multicolumn{4}{|c|}{ Bond Angles (deg) } \\
\hline $\begin{array}{l}\mathrm{N}(1)-\mathrm{Ru}(1)-\mathrm{O}(2) \\
\mathrm{C}(2)-\mathrm{O}(2)-\mathrm{Ru}(1)\end{array}$ & $\begin{array}{c}79.1(8) \\
110.7(16)\end{array}$ & $\begin{array}{l}\mathrm{C}(1)-\mathrm{N}(1)-\mathrm{Ru}(1) \\
\mathrm{O}(1)-\mathrm{N}(1)-\mathrm{Ru}(1)\end{array}$ & $\begin{array}{l}115.7(16) \\
125.9(17)\end{array}$ \\
\hline $\begin{array}{l}\mathrm{Ru}-\mathrm{N}(1) \\
\mathrm{Ru}-\mathrm{O}(1) \\
\mathrm{Ni}-\mathrm{O}(2)\end{array}$ & $\begin{array}{l}{\left[\left\{\mathrm{Ru}(\mathrm{L})_{3}\right\}\right.} \\
\text { Bond Di } \\
1.976(3) \\
2.070(3) \\
2.041(2)\end{array}$ & $\begin{array}{l}\mathrm{Ni}] \cdot 6 \mathrm{C}_{6} \mathrm{H}_{6} \\
\text { ances }(\AA) \\
\mathrm{N}(1)-\mathrm{O}(2) \\
\mathrm{N}(1)-\mathrm{C}(10) \\
\mathrm{C}(1)-\mathrm{C}(10) \\
\mathrm{C}(1)-\mathrm{O}(1)\end{array}$ & $\begin{array}{l}1.294(3) \\
1.361(4) \\
1.443(5) \\
1.276(4)\end{array}$ \\
\hline $\begin{array}{l}\mathrm{N}(1)-\mathrm{Ru}-\mathrm{N}(1) \\
\mathrm{N}(1)-\mathrm{Ru}-\mathrm{O}(1) \\
\mathrm{O}(1)-\mathrm{Ru}-\mathrm{O}(1)\end{array}$ & $\begin{array}{r}\text { Bond Ar } \\
92.16(10) \\
106.26(11) \\
86.65(10)\end{array}$ & $\begin{array}{l}\text { les (deg) } \\
\mathrm{O}(2)-\mathrm{Ni}-\mathrm{O}(2) \\
\mathrm{O}(2)-\mathrm{N}(1)-\mathrm{Ru} \\
\mathrm{N}(1)-\mathrm{O}(2)-\mathrm{Ni}\end{array}$ & $\begin{array}{l}92.33(8) \\
124.4(2) \\
119.4(4)\end{array}$ \\
\hline
\end{tabular}

ever, the meridional isomer dominates in most tris complexes due to steric reasons ${ }^{31,32}$ and we were unable to find any structurally characterized example of ruthenium(II) in a facial $\mathrm{N}_{3} \mathrm{O}_{3}$ coordination sphere. There is significant deviation from ideal octahedral geometry as reflected in the bond angles with ruthenium as the central atom. The bond distances around ruthenium are quite normal and the $\mathrm{C}-\mathrm{O}$ and $\mathrm{N}-\mathrm{O}$ lengths are comparable to those in other 2-keto-1-oximato complexes and are in accordance with structure $4 .{ }^{33,34}$ The $C_{3}$ symmetry observed in the solid state structure of $\left[\mathrm{Ru}(\mathrm{L})_{3}\right]^{-}$is also reflected in its ${ }^{1} \mathrm{H}$ NMR spectrum recorded in $\mathrm{CDCl}_{3}$ solution. Six signals (four doublets and two triplets, $1 \mathrm{H}$ each) are ideally expected provided no overlap of signals occurs, and all of them have indeed been observed (four doublets at 9.19, 7.68, 7.59, and $7.25 \mathrm{ppm}$ and two triplets at 7.43 and $7.28 \mathrm{ppm}$ ) with little overlap of the two signals at 7.25 and $7.28 \mathrm{ppm}$. This shows that the same facial stereochemistry is retained in solution as well.

The cis disposition of the three oximato functions in $\left[\mathrm{Ru}^{\mathrm{II}}(\mathrm{L})_{3}\right]^{-}$suggests the possibility of using it as a potential tridentate "ligand" which can occupy one triangular face of an octahedron. Therefore two such $\left[\mathrm{Ru}^{\mathrm{II}}(\mathrm{L})_{3}\right]^{-}$units should be capable of satisfying six coordination sites of a metal ion. We have tested this strategy with $\mathrm{Ni}^{2+}$. Reaction of $\mathrm{HNEt}_{3}\left[\mathrm{Ru}(\mathrm{L})_{3}\right]$ with $\mathrm{Ni}\left(\mathrm{ClO}_{4}\right)_{2}$ in a $2: 1$ mole ratio indeed gave the expected heterometallic trinuclear $\left[\left\{\mathrm{Ru}(\mathrm{L})_{3}\right\}_{2} \mathrm{Ni}\right]$ complex. Composition of this complex has been verified by its microanalytical data, and its formation has been authenticated by structure determination by X-ray crystallography. The structure is shown in Figure 2, and selected bond parameters are given in Table 2. The structural features in the coordination sphere around ruthenium did not change much upon trinucleation. However, bond lengths in the $\mathrm{O}-\mathrm{C}-\mathrm{C}-\mathrm{N}-\mathrm{O}$ backbone have suffered

(28) Krause, R. A.; Krause, K. Inorg. Chem. 1980, 19, 2600

(29) Dev, A. K.; Kakoti, M.; Goswami, S. J. Chem. Soc., Dalton Trans. 1991, 3249.

(30) Menon, M.; Pramanik, A.; Bag, N.; Chakravorty, A. J. Chem. Soc. Dalton Trans. 1995, 1417.

(31) Krejcik, M.; Zalis, S.; Klima, J.; Sykora, D.; Matheis, W.; Klein, A.; Kaim, W. Inorg. Chem. 1993, 32, 3362.

(32) Rutherford, T. J.; Reitsma, D. A.; Keene, F. R. J. Chem. Soc., Dalton Trans. 1994, 3659.

(33) Bisi Castellani, C.; Carugo, O.; Coda, A. Inorg. Chem. 1987, 26, 671.

(34) Carugo, O.; Djinovic, K.; Rizzi, M.; Bisi Castellani, C. J. Chem. Soc., Dalton Trans. 1991, 1255

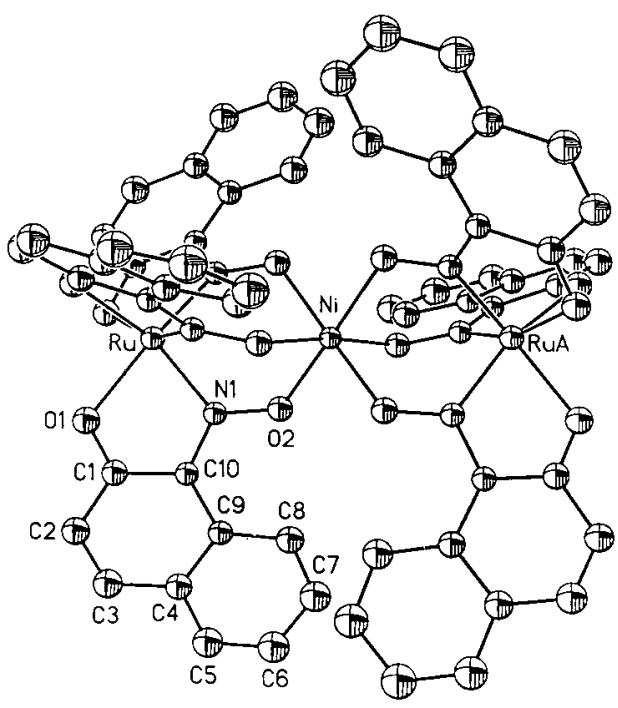

Figure 2. View of the $\left[\left\{\mathrm{Ru}(\mathrm{L})_{3}\right\}_{2} \mathrm{Ni}\right]$ molecule.

variation which is attributable to coordination of $\left[\mathrm{Ru}(\mathrm{L})_{3}\right]^{-}$to $\mathrm{Ni}^{2+}$. The central nickel ion is octahedrally surrounded by six oximato oxygens coming from the two $\left[\mathrm{Ru}(\mathrm{L})_{3}\right]^{-}$fragments. The observed $\mathrm{Ni}-\mathrm{O}$ distance is comparable to the $\mathrm{Ni}-\mathrm{O}$ distances in other structurally characterized complexes of nickel(II) with a $\mathrm{NiO}_{6}$ coordination sphere. ${ }^{35,36}$ The $\mathrm{Ru}-\mathrm{Ni}-\mathrm{Ru}$ axis is linear with a $\mathrm{Ru}-\mathrm{Ni}$ separation of $3.487 \AA$.

The $\left[\left\{\mathrm{Ru}(\mathrm{L})_{3}\right\}_{2} \mathrm{Ni}\right]$ complex is paramagnetic $\left(\mu_{\mathrm{eff}}=3.12 \mu_{\mathrm{B}}\right.$ at $298 \mathrm{~K})$, which corresponds to the +2 state of nickel $\left(\mathrm{t}_{2}{ }^{6} \mathrm{e}^{2}\right.$, $S=1)$. The infrared spectrum of $\left[\left\{\mathrm{Ru}(\mathrm{L})_{3}\right\}_{2} \mathrm{Ni}\right]$ is largely similar to that of the $\mathrm{HNEt}_{3}\left[\mathrm{Ru}(\mathrm{L})_{3}\right]$ complex. The $v_{\mathrm{NO}}$ vibration could be identified as a sharp band at $1250 \mathrm{~cm}^{-1}$ in $\mathrm{HNEt}_{3}\left[\mathrm{Ru}(\mathrm{L})_{3}\right]$ and at $1245 \mathrm{~cm}^{-1}$ in $\left[\left\{\mathrm{Ru}(\mathrm{L})_{3}\right\}_{2} \mathrm{Ni}\right]$. The electronic spectrum of $\mathrm{HNEt}_{3}\left[\mathrm{Ru}(\mathrm{L})_{3}\right]$ in acetonitrile solution shows several intense absorptions in the visible region $\left[\lambda, \mathrm{nm}\left(\epsilon, \mathrm{M}^{-1} \mathrm{~cm}^{-1}\right): 610\right.$ (18 500), 528 (17 700), 400c (9000), 350c (14 200), 316 $(15500)]^{37}$ which are probably due to allowed metal-to-ligand charge-transfer transitions. Tris complexes of ruthenium(II) showing intense absorptions in the visible region have always been of significant interest with regard to their photophysical and photochemical properties. ${ }^{38-44}$ We have checked the luminescence property of $\mathrm{HNEt}_{3}\left[\mathrm{Ru}(\mathrm{L})_{3}\right]$ in acetonitrile solution at ambient temperature $(298 \mathrm{~K})$ using an excitation wavelenth of $300 \mathrm{~nm}$, and this complex really shows emission in the visible region with two maxima at 652 and $720 \mathrm{~nm}$. Further studies on the photochemical properties of $\left[\mathrm{Ru}^{\mathrm{II}}(\mathrm{L})_{3}\right]^{-}$are in progress. In the visible region, the electronic spectrum of the $\left[\left\{\mathrm{Ru}(\mathrm{L})_{3}\right\}_{2} \mathrm{Ni}\right]$ complex in acetonitrile solution is qualitatively very similar to

(35) Ray, S.; Zalkin, A.; Templeton, D. H. Acta Crystallogr., Sect. B: Stuct. Crystallogr. Cryst. Chem. 1973, B29, 2741.

(36) Van Ingen Schenau, A. D.; Verschoor, G. C.; Romers, C. Acta Crystallogr., Sect. B: Stuct. Crystallogr. Cryst. Chem. 1974, B30, 1686.

(37) The superscript $\mathrm{c}$ indicates a shoulder.

(38) Juris, A.; Barigelletti, S.; Campagne, S.; Balzani, V.; Belser, P.; Zelewsky, A. Von. Coord. Chem. Rev. 1988, 84, 85.

(39) Baba, A. I.; Shaw, J. R.; Simon, J. A.; Thummel, R. P.; Schmehl, R. H. Coord. Chem. Rev. 1998, 171, 43.

(40) Hicks, C.; Fan, J.; Rutenberg, I.; Gafney, H. D. Coord. Chem. Rev 1998, 171, 71

(41) Stufkens, D. J.; Aarnts, M. P.; Nijhoff, J.; Rossenaar, B. D.; Vlcek, A., Jr. Coord. Chem. Rev. 1998, 171, 93

(42) Coates, C. G.; Keyes, T. E.; McGarvey, J. J.; Hughes, H. P.; Vos, J. G.; Jayaweera, P. M. Coord. Chem. Rev. 1998, 171, 323.

(43) Islam, A.; Iked, N.; Nozaki, K.; Okamoto, Y.; Gholamkhass, B.; Yoshimura, A.; Ohno, T. Coord. Chem. Rev. 1998, 171, 355.

(44) Ward, M. D.; White, C. M.; Barigelletti, F.; Armaroli, N.; Calogero, G.; Flamigni, L. Coord. Chem. Rev. 1998, 171, 481 
that of the parent $\mathrm{HNEt}_{3}\left[\mathrm{Ru}(\mathrm{L})_{3}\right]$ complex $\left[\lambda, \mathrm{nm}\left(\epsilon, \mathrm{M}^{-1}\right.\right.$ $\mathrm{cm}^{-1}$ ): 624 (10 300), 550 (12 500), 400 (7400), 350 (9600), $\left.320^{\mathrm{c}}(10700)\right] .{ }^{37}$ However, it shows an additional weak absorption at $972 \mathrm{~nm}\left(\epsilon, 100 \mathrm{M}^{-1} \mathrm{~cm}^{-1}\right)$, which is assignable to the ${ }^{3} \mathrm{~A}_{2} \rightarrow{ }^{3} \mathrm{~T}_{2}$ transition of the $\mathrm{NiO}_{6}$ fragment. ${ }^{45}$

Cyclic voltammetry on the $\mathrm{HNEt}_{3}\left[\mathrm{Ru}(\mathrm{L})_{3}\right]$ complex in acetonitrile solution shows two oxidative responses on the positive side of SCE. The first oxidation, observed at $0.50 \mathrm{~V}$, is reversible and is assigned to the $\mathrm{Ru}^{\mathrm{II}}-\mathrm{Ru}^{\mathrm{III}}$ oxidation. ${ }^{46}$ It may be mentioned here that the appearance of $\mathrm{Ru}^{\mathrm{II}}-\mathrm{Ru}^{\mathrm{III}}$ oxidation in the $\left[\mathrm{Ru}^{\mathrm{II}}(\mathrm{L})_{3}\right]^{-}$complex near the observed potential was predicted in our earlier report on some mixed-ligand 1-nitroso-2-naphtholate complexes of ruthenium. ${ }^{47}$ The second oxidation, observed at $1.35 \mathrm{~V}$, is irreversible and is tentatively assigned to the $\mathrm{Ru}^{\mathrm{III}}-\mathrm{Ru}^{\mathrm{IV}}$ oxidation. The cyclic voltammetric behavior of $\left[\left\{\mathrm{Ru}(\mathrm{L})_{3}\right\}_{2} \mathrm{Ni}\right]$ is qualitatively similar with that of the parent $\left[\mathrm{Ru}^{\mathrm{II}}(\mathrm{L})_{3}\right]^{-}$complex showing two oxidative responses at 0.51 and $1.50 \mathrm{~V}$. The $\mathrm{Ni}^{\mathrm{II}}-\mathrm{Ni}^{\mathrm{III}}$ oxidation, which is known to occur at a high potential in complexes with a $\mathrm{NiO}_{6}$ coordination sphere, ${ }^{48}$ could not be observed within the voltage window offered by the solvent.

(45) Sutton, D. Electronic spectra of Transition Metal Complexes; McGrawHill: London, 1968; pp 147-148.

(46) An oxidative response with small current heights is also observed at $0.65 \mathrm{~V}$ vs SCE (which is not due to any impurity in the sample), the origin of which is yet to be understood.

(47) Ghatak, N.; Bhattacharya, S. Transition Met. Chem. 1996, 21, 423.
The present study shows that the $\left[\mathrm{Ru}^{\mathrm{II}}(\mathrm{L})_{3}\right]^{-}$complex is a potential tridentate "ligand" which can be utilized as an efficient building unit for the construction of polymetallic assemblies. The use of this complex to form heterometallic di- and trinuclear complexes is in progress. The redox activity and photochemistry of $\left[\mathrm{Ru}^{\mathrm{II}}(\mathrm{L})_{3}\right]^{-}$appear interesting and are currently under investigation.

Acknowledgment. Financial assistance received from the Council of Scientific and Industrial Research, New Delhi [Grant No. 01(1408)/96/EMR-II], and the Spanish Directorate General for Higher Education (Grant No. PB95-0792) are gratefully acknowledged. Thanks are also due to the Third World Academy of Sciences for financial support for the purchase of an electrochemical cell system. The authors thank Dr. Rupendranath Banerjee and Dr. Nitin Chattopadhyay of Jadavpur University for their help.

Supporting Information Available: Tables containing crystal data and details of structure determination, atomic coordinates, anisotropic thermal parameters, and bond distances and angles for $\mathrm{HNEt}_{3}\left[\mathrm{Ru}_{-}\right.$ $\left.(\mathrm{L})_{3}\right] \cdot 2 \mathrm{C}_{6} \mathrm{H}_{6}$ and $\left[\left\{\mathrm{Ru}(\mathrm{L})_{3}\right\}_{2} \mathrm{Ni}\right] \cdot 6 \mathrm{C}_{6} \mathrm{H}_{6}$, absorption and emission spectra of $\mathrm{HNEt}_{3}\left[\mathrm{Ru}(\mathrm{L})_{3}\right]$, and ${ }^{1} \mathrm{H}$ NMR spectrum of $\operatorname{HNEt}_{3}\left[\mathrm{Ru}(\mathrm{L})_{3}\right]$. This material is available free of charge via the Internet at http://pubs.acs.org.

\section{IC990191A}

(48) Bhattacharya, S.; Mukherjee, R.; Chakravorty, A. Inorg. Chem. 1986, $25,3448$. 